\title{
Discussion about progressive collapse of masonry buildings
}

\section{Discussão sobre colapso progressivo em edifícios de alvenaria estrutural}
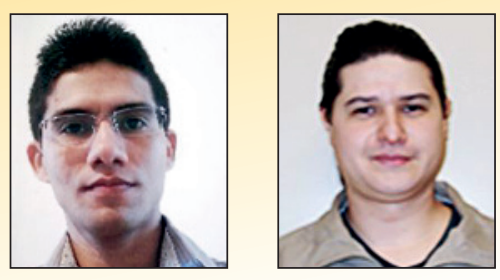

T. R. C. FELIPE tulio-raunyr@usp.br https://orcid.org/0000-0002-3958-4643

V. G. HAACH vghaach@sc.usp.br https://orcid.org/0000-0002-9501-4450

\begin{abstract}
Most standards indicate the need of the evaluation of abnormal loads in the structural design, but in general, they do not provide many details about these actions and how to consider them in the design. The consequence of not considering these actions may be to the progressive collapse of the structure. This type of failure can be avoided by design of elements with sufficient robustness to control possible localized damage, ensuring adequate time for emergency measures to be taken. This work aims to discuss the progressive collapse and the behavior of masonry buildings subject to abnormal loads. An extensive literature review is carried out, highlighting the main procedures and strategies to mitigate this issue and the guidelines available in the standards. It is concluded that there is still an absence of works that deal with this kind of action in masonry buildings.
\end{abstract}

Keywords: masonry, abnormal loads, progressive collapse, robustness.

\section{Resumo}

A maioria dos códigos normativos cita a necessidade da avaliação de ações excepcionais no projeto de estruturas, porém sem fornecer muitos detalhes de quais seriam estas ações e como considerá-las. A consequência da não consideração destas ações pode levar ao colapso progressivo da estrutura. Este tipo de ruína pode ser evitado projetando-se estruturas com robustez suficiente para controlar possíveis danos localizados, proporcionando tempo suficiente para que medidas de emergência sejam realizadas. Este trabalho tem como objetivo discutir o colapso progressivo e o comportamento de edifícios em alvenaria estrutural sujeitos a ações excepcionais. Para tal, uma extensa revisão teórica é realizada, destacando os principais procedimentos e estratégias para mitigação dessa problemática e as diretrizes de projeto disponíveis nos códigos normativos. Conclui-se que ainda faltam trabalhos específicos que tratam sobre as ações excepcionais em edifícios de alvenaria estrutural.

Palavras-chave: alvenaria, danos acidentais, colapso progressivo, robustez. 


\section{Introduction}

The federal government social programme Minha Casa Minha Vida boosted the construction system named structural masonry all over the country. This system has become a sustainable technological alternative to residential construction building for the middle-class and lower-middle-class families. Brazilian builders have been widely applied it to the new projects.

Since, the increase in productivity due to the characteristics of modulation and rationalization of this process reflects in the decrease of material waste and the final costs of the building.

In masonry buildings, the wall is the structural element, which means damages or possible removal of these elements may lead to serious risk of structural collapse due to the appearance of additional internal forces. Unfortunately, due to the ignorance of some users, it is common in residential buildings, the removal of walls to increase environments without the permission of technical person responsible for the project. Therefore, there is a great concern about the occurrence of abnormal loads, which generate disproportional damages.

The abnormal loadings (vehicle impact, gas explosion, terrorist attack, etc.) are not usually considered in building designs due to their low probability of occurrence. Nevertheless, in the occurrence of these events, several problems can occur in the structures, such as the progressive collapse. The accident at the Ronan Point Building in 1968 in the city of London started the search for better predictions of abnormal loads and progressive collapse in structures. This event resulted in the update of international recommendations and standards.

The Brazilian masonry building standards, [1] and [2], published in 2010 and 2011, respectively, have not specific design guidelines about abnormal loadings or progressive collapse. However, they have informative annexes with some general recommendations about these subjects.

Concerning concrete structures, the Brazilian standard [3] cites the ultimate limit state of progressive collapse as something to be checked to ensure the safety of structures. In sections 19.5 and 20.3 the standard recommends additional reinforcements for slabs in order to guarantee local ductility and consequently protection against progressive collapse. The precast concrete standard [4] in section 5.1.1.4 emphasizes that the engineer should take special care in detailing the structure to minimize the occurrence of progressive collapse. On the other hand, standard of concrete wall castes in place for residential buildings [5] does not comment anything about this subject. Therefore, it should be highlighted that only some Brazilian standards indicate the concern regarding abnormal loadings and progressive collapse, however, without many guidelines to help on the building design. The historical of structures that have undergone the progressive collapse in Brazil, such as the Liberdade Building in Rio de Janeiro in 2012, with the death 22 people, shows that engineers should discuss more this subject. Therefore, this work intends to discuss current strategies to mitigate progressive collapse in masonry structures. Note that design a masonry structure by evaluating the possibility of abnormal loadings, with the goal of reducing the probability of occurrence of progressive collapse, requires a differentiated view of the engineer.
Also, the load combinations described in Brazilian standards do not take into account their effects on structures.

\section{Abnormal loads and progressive collapse}

Failure of a structure subjected to abnormal loadings is associated with significant economic implications and severe social repercussions. Although abnormal loadings and progressive collapse is events with a low probability of occurrence, their consequences have a deep impact on society due to the loss of life.

Several authors ([6], [7] and [8]) assert that events that include abnormal loads are not generally considered in building design, which implies the possibility of loss of structural integrity due to their occurrences. Also, such loads may lead to the partial or total collapse of buildings and loss of a high number of human lives ([9], [10], [11] and [12]).

Ellingwood [13] and Eurocode [14] recommend that the damage in the building after abnormal loads does do not exceed $15 \%$ of the floor area, nor $100 \mathrm{~m}^{2}$, and, in the vertical direction, does not extend beyond the adjacent floors to the location of the event. However, Eurocode [14] emphasizes that localized damage to a structural element may be acceptable if the building preserves its structural integrity for a sufficient period to allow necessary emergency measures to be take.

The researchers ([15] and [16]) point out that currently, the standard that more details the progressive collapse is the UFC [17]. Nevertheless, this standard is more suitable for frame structures, where the loss of a column instantly in a possible abnormal loading is the primary factor that takes in the occurrence of a progressive collapse.

Progressive collapse can be understood as an "incremental" rupture and develops, in a chain reaction mechanism, in which cause the failure of the building. If the structure has not sufficient robustness, abnormal loads cause localized damages that construction cannot absorb or contain. Accordingly, the final state is disproportionate to the event that initiated it ([18], [19] e [20]). For researchers [6] and [21] progressive collapse is the gradual failure of the building due to initial damage to an element that leads to the rupture of the structure or part of it.

Ellingwood [11] and Dusenberry [22] affirm that specific designs that ensure safety from abnormal loads have not been standardized in the United States or nowhere else in the world. Nevertheless, codes dealing with the progressive collapse use an empirical approach to this issue through passive guidelines to increase the robustness of the structure.

The classical examples of progressive collapse into buildings mentioned in the literature review have been in concrete and mostly in precast concrete structures because given the lack of continuity in the link of the structural system these are more susceptible to collapse.

Concerning the progressive collapse in masonry buildings, there are insufficient guidelines, since the works that deal with the subject do not show the needed procedures to minimize their occurrence. This lack of guidelines is due to the difficulty of evaluating the fragile, heterogeneous and anisotropic behavior of masonry ([16]). 
One of the first works to deal with the progressive collapse in masonry structures was performed by Mcguire [23]. This researcher conducted a case study on the progressive collapse of masonry building in the prevention of abnormal load through the British standard [30]. The author recommends that the structure is analyzed through the alternate load paths and the specific local resistance, both procedures described in section 3 .

Hendry [24] made a study of the fundamental architectural concepts of masonry buildings regarding abnormal loads. This author verified three basic kinds of architectural details that need particular attention: a) external wall without flange; b) internal wall without flange; and c) when the removal of a wall produces a large stress concentration in a small area of other walls.

Ellingwood et al. [25] through a structural reliability analysis conducted a case study for an eight-story building of ceramic blocks masonry. The abnormal load of the building was based, on an explosion in the kitchen of an apartment on the eighth floor. Such strategy was used to demystify the idea that structural elements in upper floors would not lead to the collapse of the structure. These researchers calculated the probability of failure of the structure considering the failure mode of the flexural compression walls measuring values of the order of $10^{-4}$ and $10^{-6}$, respectively, in the eighth and first floor. They concluded that the lack of continuity and ductility of masonry structures make them susceptible to progressive collapse.

\section{The mitigating risk from abnormal loads and progressive collapse}

In the design of a building, the engineer should consider the dead and live loads with their partial and representative factors in the load combinations described by the standards.

The load combinations take into account the occurrence of the actions from low-probability and high-consequence events, providing a safety margin against minor abnormal loads. However, the engineer should ensure that the structure has sufficient redundancy, strength, and ductility to mitigate the event of a progressive collapse.

Due to the low probability of abnormal loads, it is common the engineers address passive protection measures rather than evaluate those loads in the structure. Such measures are carried out by introducing ties anchored along some predefined structural elements ([17], [18] e [19]). However, those measures are obtained from laws of a phenomenological nature. Therefore, the use of ties may generate an undesirable effect because there is a probability that in the event of a localized collapse, other interconnected elements will be pulled, becoming a chain reaction mechanism that can cause the progressive collapse of the structure.

In the literature, the term robustness often appears as a way to minimize the damage caused by the progressive collapse. Nevertheless, there is not general agreement about the precise meaning of robustness.

UFC [17], ASCE 7 [18], NISTIR [19] and GSA [26], prescribe two approaches to project building structures considering the possibility of progressive collapse: indirect design and direct design.

\subsection{Indirect design approach}

The indirect design approach consists implicitly of predicting minimum requirements of strength, continuity, and ductility. These requirements are satisfied when the engineer uses one of the following standards UFC [17], ASCE 7 [18], NISTIR [19] and GSA [26]. However, the indirect design guidelines alone do not guarantee structural integrity in the eventual progressive collapse of the structure. In the indirect design approach, the engineer can still use the Tie Force method. This procedure consists to enhance continuity, ductility, and structural redundancy by specifying minimum tensile forces through ties that should be used to attach the structure.

To mobilize alternative paths for the load transfer in case of a localized failure of a structural element, the engineer must use extra ties anchored in the structural elements, not provided for in the usual design of the structure. UFC [17] prescribes the horizontal ties must be provided: longitudinal, transverse, and peripheral between beams and slabs. Vertical ties are applied in columns and load-bearing walls.

To use this approach, the engineer must check following equation of ultimate limit state:

$\emptyset R_{n} \geq R_{u}$

where, $\phi$ is the strength reduction factor, $R_{n}$ is the nominal tie strength calculated with the appropriate material specific code, including the over-strength factors form Chapters 5 to 8 of ASCE 41 [27], and $R_{u}$ is the required tie strength.

To uniform floor load the required tie strength is determinate by following load combination:

$w=1.2 F_{g}+0.5 F_{g}$

Where, $w$ is the floor load $\left(\mathrm{KN} / \mathrm{m}^{2}\right), F_{g}$ is the dead load $\left(\mathrm{KN} / \mathrm{m}^{2}\right)$, and $F_{q}$ is the live load $\left(\mathrm{KN} / \mathrm{m}^{2}\right)$.

From the slab shown in Fig. $1 \mathrm{a}$ ), it is possible to deduce an equation for the calculation of the required tie strength in the limit situation, considering the deformed position of the slab after the removal of support at point B in Fig. 1 b).

By equilibrium of moments at point B' Fig.1 b), the required tie strength is written by Eq. (3).

$F_{t}=\frac{w\left(L_{1}+L_{2}\right)^{2}}{8 \delta v}=R_{u}$

The needed reinforcement to ensure continuity by the supports is calculated by Eq. (4).

$A_{s}=\frac{F_{t}}{\emptyset R_{n}}$

\subsection{Direct design approach}

Direct design approach considers the resistance to progressive collapse explicitly. This approach includes the specific local resistance (SLR) method and alternate load paths (ALP) method.

\subsubsection{Specific local resistance (SLR)}

This method provides extra strength in key elements that are needed for overall stability. The SLR is used for a predefined event. Therefore, the engineer evaluates the efforts in the structural elements considering in the load combinations their several effects, for instance, terrorist attacks, explosions, fires, and earthquakes. According to Ellingwood [28], one way of implementing this approach is merely to increase the partial factors of safety over the 
usual design loads. However, increasing the partial factors of safety may not be an adequate solution. Because when the structure is subjected to collapse, the failure modes may be different from those initially considered to calibrate the factors. Thus, its increase to the current failure modes becomes irrelevant.

\subsubsection{Alternate load paths (ALP)}

The ALP approach focuses on the evaluation of the behavior of the structure following the occurrence of the removal of load-bearing elements. Thus, the structural system should be capable of bridging over a missing structural component. Nevertheless, UFC [17] comment that the application of this approach must be evaluated through 3D modeling of the structure.

According to the UFC [17] and GSA [26], three analysis procedures can be used to evaluate the ALP; they are linear static analysis, nonlinear static analysis, and nonlinear dynamic analysis. Regardless of the analysis considered, it is necessary to analyze the structure acceptance criterion. The demand-capacity ratio (DCR) performs this evaluation. The DCR is defined by:

$D C R=\frac{Q_{u d, l i m}}{Q_{c e}}$

where, $Q_{u d, l i m}$ is the resulting actions (internal forces and moments) after to apply the ALP, and $Q_{c e}$ is the expected strength of the component or element, as specified in Chapters 4 to 8 of the UFC [17] The value of the DCR must be in the restricted range between 1 and 2. Consequently, structural elements outside these limits have a high probability of collapse.

To evaluate the Eq. (5) the engineer must carry out a check in the deformation-controlled actions and force-controlled actions. According to UFC [17] and GSA [26], to compute the deformationcontrolled actions, followed loads combination should simultaneously applied:

I) Increased gravity loads for floor areas above removed column or wall.

$G_{l d}=\Omega_{l d}\left[1.2 F_{g}+\left(0.5 F_{q}\right.\right.$ or $\left.\left.0.2 F_{s}\right)\right]$

where, $G_{\text {Id }}$ is the increased gravity loads for deformation-controlled actions for linear static analysis, $\Omega_{\mathrm{ld}}$ is the load increase factor for calculating deformation-controlled actions for linear static analysis defined in Table 3.4 of the UFC [17], and $F_{s}$ is the snow load.
II) Gravity loads for floor areas away from the removed column or wall.

$G=\left[1.2 F_{g}+\left(0.5 F_{q}\right.\right.$ or $\left.\left.0.2 F_{s}\right)\right] \therefore G=$ gravity loads

Load case for force-controlled actions must be calculated simultaneously applying the following loads combination ([17] and [26]).

III) Increased gravity loads for floor areas above removed column or wall.

$G_{l f}=\Omega_{l f}\left[1.2 F_{g}+\left(0.5 F_{q}\right.\right.$ or $\left.\left.0.2 F_{s}\right)\right]$

where, $G_{\text {If }}$ is the increased gravity loads for force-controlled actions for linear static analysis, $\Omega_{\text {|f }}$ is the load increase factor for calculating force-controlled actions for linear static analysis defined in Table 3.4 of the UFC [17].

IV) Gravity loads for floor areas away from the removed column or wall: use Eq. (7) to compute the load G.

Due to the complexity, nonlinear procedures have been used less frequently for progressive collapse analyses than that linear procedures. However, according to GSA [26], if the engineer has knowledge and experience about nonlinear analysis he can use following those loads combination to perform this analysis.

V) Static analysis loading.

$G_{s l n}=2\left(F_{g}+0.25 F_{q}\right) \therefore G_{s l n}=$ static load for nonlinear analysis

VI) Dynamic analysis loading.

$G_{d l n}=\left(F_{g}+0.25 F_{q}\right) \therefore G_{d l n}=$ dynamic load for nonlinear analysis

Additionally, the engineer must evaluate acceptance criteria for the nonlinear analysis presented in Table 2.1 of the GSA [26].

\section{Current standard approaches progressive collapse}

Nowadays, the consideration of abnormal loads and progressive collapse in new building construction has been inserted into the main standards as UFC [17], ASCE 7 [18], NISTIR [19] and GSA [26] and the Russian standard STO [29], which establish guidelines for prevention of progressive collapse of frame structures. Concerning masonry buildings, UFC [17] in Chapter 6 prescribes

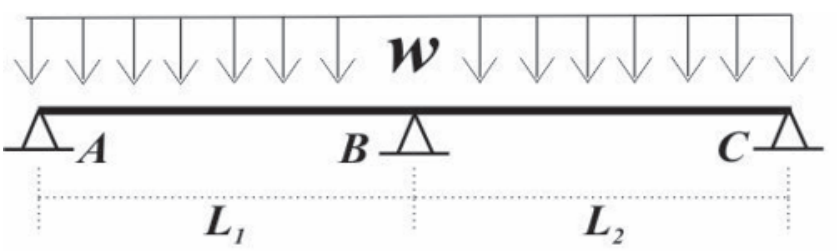

a)

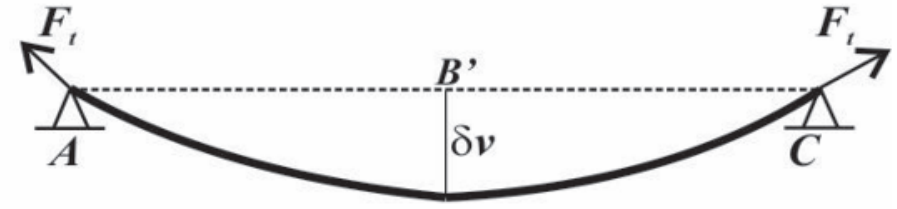

b)

Figure 1

a) removal of the slab support at point B; b) deformed position after removal of support at point B 
that these buildings be analyzed by the tie force requirements or by the alternate load path method.

NISTIR [19] prescribe in section 4.2.2 that peripheral and horizontal ties should be provided along the whole perimeter within a nominal distance of slab edge in case of masonry structures. Those ties should be anchored at reentrant corners, wheras, vertical ties shall be fixed floor-to-floor at load-bearing walls. According to section 5.4.2 of the NISTIR [19], the following design checks should be evaluated for enhancing the robustness of masonry buildings. The membrane behavior of slabs should be consolidated providing additional reinforcements if possible. Concerning reinforced masonry, should provide continuous steel in both directions; provide at least one horizontal bar along each course and one vertical bar in each cell so that wall has potential to support an eventual abnormal loading.

To consider abnormal loads, ASCE 7 [18] prescribes the following gravity load combination $\left(G_{d}\right)$ :

$G_{d}=(0.9$ or 1.2$) F_{g}+F_{a b n}+0.5 F_{q}+0.2 F_{w}$

in which, $F_{w}$ is the wind load, and $F_{a b n}$ is the load or load effect resulting from an abnormal load. Concerning to $F_{a b n}$, the engineer can use a force, for instance, such as an explosion or impact, or deformation related, as in case of fire.

GSA [26] and STO [29] deal with guidelines on concrete structures and not comment on abnormal load and progressive collapse in masonry buildings structural.

A code that highlights particular comments in the guidelines of abnormal loads and progressive collapse for masonry buildings structural is the British standard BS 5628 [30]. BS 5628 [30] differs from other standards since addressed the first guidelines to minimize the occurrence of the abnormal loads. This code in section 37 prescribes recommendations by the tie force approach, which should be considered in design to mitigate the effects of the progressive collapse.

Table 13 of the BS 5628 [30] presents the requirements for full peripheral $\left(T_{p}\right)$ and internal $\left(T_{i}\right)$ ties, according to following equations:

$f_{t}(K N)=\left\{\begin{array}{c}60 \\ 20+4 N_{s}\end{array}\right.$

$T_{p}=f_{t}$

$T_{i}(K N) \leq\left\{\begin{array}{c}f_{t} \\ \frac{f_{t}\left(F_{g}+F_{q}\right)}{7.5}\left(\frac{L_{a}}{5}\right)\end{array}\right.$

in which, $f_{t}$ is the basic horizontal tie force, $N_{s}$ is the number of stories (including ground and basement), and $L_{a}$ is whichever is the lesser of: the greatest distance in meters in the direction of the tie, between the centers of columns or other vertical loadbearing members whether this distance is spanned by a single slab or by a system of beams and slabs; or 5 times floor-to-floor heights.

Additionally, BS 5628 [30] address the Eq. (15) to evaluate ties into an external column or wall.

$T_{e}(K N) \leq\left\{\begin{array}{c}2 f_{t} \\ f_{t}\left(\frac{h}{2.5}\right)\end{array}\right) \therefore h=$ floor - to - floor height in meters

Regarding requirements for full vertical ties, BS 5628 [30] recommend:
I) The minimum thickness of a solid wall or one load bearing leaf of a cavity wall is equal to $150 \mathrm{~mm}$;

II) The minimum characteristic compressive strength of masonry equal to $5 \mathrm{MPa}$;

III) The ratio between the free height of a column or wall between restraining surfaces and their thickness must be less than or equal 20 times;

IV) Vertical tie force $\left(T_{v}\right)$ given by:

$T_{v}(K N) \geq\left\{\begin{array}{c}100 L_{e} \\ \frac{34 A}{8}\left(\frac{h}{t}\right)^{2}\end{array}\right.$

in which, respectively, $L_{e}$ is the length, $t$ is the thickness, and $A$ is the horizontal cross-sectional area in $\mathrm{mm}^{2}$ of the wall or column.

V) The distance of ties 5 meters maximum along the wall and 2.5 meters maximum from a free end of any wall.

Nevertheless, BS 5628 [30] does not comment direct design guidelines as a solution to increase the structural integrity of masonry buildings structural.

\section{Current research}

With concerns about terrorist attacks on buildings several researchers ([31], [32], [33], [34], [35] and [36]) began to study the behavior of structures when subjected to explosions. These studies were generally restricted to concrete and steel structures.

Regarding masonry buildings, in 2013, researchers from McMaster University, Canada, conducted experimental tests on three reinforced masonry walls to evaluate their response when subjected to an explosion. These walls were compared with unreinforced masonry walls subjected to the same explosion loads. The level of permanent strain was significantly lower in the reinforced masonry walls, shown its ability to prevent progressive collapse [37].

Lu et al. [38] and Pham et al. [39] evaluated the behavior of slabs in the occurrence of a progressive collapse. These authors concluded that the residual strength of slabs, given by membrane mechanisms contribute to the resistance of progressive collapse. However, it is needed to analyze the influence of the interaction between the beams and slabs, given the removal of a support element.

Felipe [40] proposed a Systematic Reliability-based Approach to Progressive Collapse (SRAPC). This procedure provides a more accurate measurement of risks through an approach that uses structural reliability analysis [41]. Also, it is possible to determine the coefficients of importance and vulnerability to identify the key elements for structure. The identification of these elements is useful since the engineer can increase its strength to mitigate the occurrence of the progressive collapse [41].

\section{Future perspectives}

The future perspectives are to insert the structural reliability analysis and SRAPC approach to evaluate the effects of the abnormal loads and progressive collapse. Thus, to determine the key elements and to prescribe guidelines based on a probabilistic theory. Therefore, providing robustness and structural integrity to new building designs. 


\section{Conclusions}

The paper concludes that there is lack of publications that address the probability of failure of masonry buildings when subjected to abnormal loads. The way in which standards deal with the progressive collapse of the masonry buildings using the indirect design approach and passive guidelines does not allow complete prevention when abnormal loads occur. These codes do not measure the probability of collapse of the structure, as well as they do not detect the most vulnerable elements.

In most cases, the guidelines of the codes established ties between slabs and walls to provide local ductility in the structure. It is known that these ties increase the continuity of the links between the structural elements and consequently the robustness of the structure. However, the failure of a wall can influence other walls resulting in a chain effect that culminates in the progressive collapse of the structure. Also, there is lack of publications in the review literature that measure the efficiency of these ties in mitigating abnormal loads.

\section{Acknowledgments}

This study was financed in part by Coordenação de Aperfeiçoamento de Pessoal de Nível Supereior - Brasil (CAPES) - Finance Code 001 and Conselho Nacional de Desenvolvimento Científico e Tecnológico - Brasil (CNPq).

\section{References}

[1] ASSOCIAÇÃO BRASILEIRA DE NORMAS TÉCNICAS. Alvenaria Estrutural - Blocos Cerâmicos Parte 1: Projeto. NBR 15812, Rio de Janeiro, 2010.

[2] ASSOCIAÇÃO BRASILEIRA DE NORMAS TÉCNICAS. Alvenaria Estrutural - Blocos de Concreto Parte 1: Projeto. - NBR 15961 , Rio de Janeiro, 2011.

[3] ASSOCIAÇÃO BRASILEIRA DE NORMAS TÉCNICAS. Projeto e Execução de Obras de Concreto Armado - Procedimentos. - NBR 6118, Rio de Janeiro, 2014.

[4] ASSOCIAÇÃO BRASILEIRA DE NORMAS TÉCNICAS. Projeto e Execução de Estruturas de Concreto Pré-moldado. - NBR 9062 , Rio de Janeiro, 2006.

[5] ASSOCIAÇÃO BRASILEIRA DE NORMAS TÉCNICAS. Parede de Concreto Moldada no Local para a Construção de Edificações - Requisitos e Procendimentos. - NBR 16055, Rio de Janeiro, 2012.

[6] KOZLOVA, P. The phenomenon of progressive collapse according to Russian norms, Lappeenranta, 2013, Bachelor's Thesis - Saimaa University of Applied Sciences, $93 \mathrm{p}$.

[7] VASILIEVA, A. Progressive collapse and methods of prevention, Lappeenranta, 2013, Bachelor's Thesis - Saimaa University of Applied Sciences, $86 \mathrm{p}$.

[8] Ellingwood B, Leyendecker EV, James TP. Probability of failure from abnormal load. Journal of Structural Engineering, v.109, n.4, 1982; p.875-890.

[9] HAACH, V. G. Danos acidentais. In: Construções em Alvenaria Estrutural: Materiais, Projeto e Desempenho, São Paulo: Blucher, 1ed, 2015, cap.7, p.219-231.
[10] ELLINGWOOD, B. Strategies for mitigating risk of progressive collapse. In: ASCE/SEI Structures Congress, New York, 2005

[11] Ellingwood B, Dusenberry DO. Building design for abnormal loads and progressive collapse. Computer-Aided Civil and Infrastructure Engineering, v.20, s/n, 2005; p.194-205.

[12] Ellingwood B. Mitigating risk from abnormal loads and progressive collapse. Journal of Performance of Constructed Facilities, v.20, n.4, 2006; p.315-323.

[13] Ellingwood B. Strategies for mitigating risk to buildings from abnormal load events. International Journal of Risk Assessment and Management, v.6-7, n.6, 2007; p.828-845.

[14] EUROPEAN STANDARD. Actions on Structures part 1-7. Eurocode 1, Brussels, 2003.

[15] Dat PX, Hai TK, Jun Y. A simplified approach to assess progressive collapse resistance of reinforced concrete framed structures. Journal Engineering Structures, v.101, s/n, 2015; p.45-57.

[16] KOUSGAARD A, ERDOGMUS E. State-of-the-art review: analysis and rehabilitation of existing masonry walls against progressive collapse. In: AEI 2015: Birth and Life of the Integrated Building - Proceedings of the AEI Conference 2015. [S.L.: s.n], 2015. p. 421-432.

[17] DEPARTMENT OF DEFENSE. Design of building to resist progressive collapse. - UFC 4-023-03, Washington, 2009.

[18] AMERICAN SOCIETY OF CIVIL ENGINEERS. Minimum design loads for buildings other structures. - ASCE 7, Reston, VA, 2005.

[19] NATIONAL INSTITUTE OF STANDARD AND TECHNOLOGY. Best practices for reducing the potential for progressive collapse in buildings, technology administration. - NISTIR 7396, Gaithersburg, MD, 2007.

[20] Laranjeiras, A. Colapso progressive dos edifícios: breve introdução. TQS News, 2011; p.36-48.

[21] HABERLAND M, STAROSSEK U. Progressive collapse nomenclature. In: ASCE/SEI Structures Congress, New York, 2009.

[22] DUSENBERRY DO, JUNEJA G. Review of existing guidelines and provisions related to progressive collapse. In: Workshop on Prevention of Progressive Collapse, [S.L], 2002.

[23] MCGUIRE W. Prevention of progressive collapse. In: Proc. Regional Conf. on Tall Buildings, Institute of Technology, Thailand, 1974. p. 851-865.

[24] HENDRY, A. W. Structural Brickwork. Halsted Press, 1981.

[25] Ellingwood B, Leyendecker EV, Yao JTP. Probability of failure from abnormal load. Journal of Structural EngineeringASCE, v.109, n.4, 1983, p. 875-890.

[26] GENERAL SERVICES ADMINISTRATION. Progressive collapse analysis and design guidelines for new federal buildings and major modernization projects. - GSA, Washington, DC, 2003.

[27] AMERICAN SOCIETY OF CIVIL ENGINEERS. Seismic rehabilitation of existing buildings. - ASCE 41, Reston, VA, 2006.

[28] ELLINGWOOD B, LEYENDECKER EV. Design methods for reducing the risk of progressive collapse in buildings, 
[S.L]: US Dept. of Commerce, National Bureau of Standards, 2ed, 1977.

[29] STO. Prevention of progressive collapse of reinforced concrete monolithic structures of buildings. - STO-00802495342, Moscow, 2009.

[30] BRITISH STANDARDS INSTITUTION. Code of practice for use of masonry - part 1. - BS 5628-1, London, 1992.

[31] Smith PP, Byfield MP, Goode DJ. Buildings robustness research during world war II. Journal of Performance of Constructed Facilities, v.24, n.6, 2010; p.529-535.

[32] Wu CQ, Hao H. Safe scaled distance for masonry infilled $\mathrm{RC}$ frame structures subjected to airblast loads. Journal of Performance of Constructed Facilities, v.21, n.6, 2007; p.422-431.

[33] Luccioni BM, Ambrosini RD, Danesi RF. Analysis of buildings collapse under blast loads. Journal Engineering Structures, v.26, $s \ln , 2004 ;$ p.63-71.

[34] Corley WG, Mlakar PF, Sozen MA, Thornton CH. The Oklahoma City bombing: summary and recommendations for multihazard mitigation. Journal of Performance of Constructed Facilities, v.12, n.3, 1998; p.100-112.

[35] Longinow A, Mniszewski KR. Protection buildings against vehicle bomb attacks. Journal Practice Periodical on Structural Design and Construction, v.1, n.1, 1996; p.51-54.

[36] Yokel FY, Wright RN, Stone WC. Progressive collapse: US office buildings in Moscow. Journal of Performance of Constructed Facilities, v.3, n.1, 1989; p.57-75.

[37] EI-DAKHAKHI W, MEKKY W, TAIT M, SIMONDS K, ELSAYE M. Resilient reinforced masonry loadbearing wall system to mitigate progressive collapse. In: 10th International Conference on Shock and Impact Loads on Structures, [S.I], 2009, p. $173-181$

[38] Lu X, et al.. Experimental investigation of RC beam-slab substructures against progressive collapse subject to an edge-column-removal scenario. Engineering Structures, Elsevier, 2016

[39] Pham AT, Tan KH, Yu J. Numerical investigations on static and dynamic responses of reinforced concrete sub-assemblages under progressive collapse. Engineering Structures, Elsevier, 2016.

[40] FELIPE, T. R. C. Novo método para a avaliação do risco do colapso progressivo em edifícios de alvenaria estrutural, São Carlos, 2017, Dissertação (Mestrado) - Escola de Engenharia de São Carlos, Universidade de São Paulo, 148 p.

[41] Felipe TRC, Haach VG, Beck AT. Systematic reliabilitybased approach to progressive collapse. ASCE-ASME Journal of Risk and Uncertainty in Engineering Systems - Part A: Civil Engineering, v.4, n.4, 2018, p.04018039-9. 